\title{
Inhibition of AGS human gastric cancer cell invasion and proliferation by Capsosiphon fulvescens glycoprotein
}

\author{
YOUNG-MIN KIM, IN-HYE KIM and TAEK-JEONG NAM \\ Institute of Fisheries Sciences, Pukyong National University, Ilgwang-ro, \\ Ilgwang-myeon, Gijang-gun, Busan 619-911, Republic of Korea
}

Received January 24, 2013; Accepted May 20, 2013

DOI: $10.3892 / \mathrm{mmr} .2013 .1492$

\begin{abstract}
Seaweeds are increasingly being used as foodstuffs and therapeutics. Capsosiphon fulvescens (C.fulvescens) is a green sea alga which has demonstrated anti-tumor activity in various cancer cell lines. In cancer cells, homeostasis is not maintained, enabling mutations to develop and growth to continue unchecked. Overexpression of matrix metalloproteinase (MMP) and tight junction (TJ) proteins is important for cancer cell proliferation, invasion and metastasis. In addition, these proteins are closely associated with cell membrane permeability. In the current study, $C$. fulvescens glycoprotein (Cf-GP) was found to inhibit TJ proteins and invasion of AGS human gastric cancer cells. Cf-GP-mediated inhibition of cell proliferation and invasion was confirmed, as well as changes in TJ protein levels. In addition, MMP-2 and -9 activities were inhibited, as indicated by increased transepithelial electrical resistance. Inhibition of MMP protein expression was also found to correlate with tissue inhibitor of metalloproteinase 1 and Cf-GP treatment, as revealed by western blot analysis and RT-PCR. In conclusion, these results indicate that Cf-GP inhibits cancer cell invasion and therefore demonstrates a potential therapeutic strategy to decrease cancer metastasis.
\end{abstract}

\section{Introduction}

Cells become cancerous as a result of mutation of normal genes, resulting in continuous growth and survival. Human gastric cancer is linked to irregular eating habits and intake of fast food (1). In recent years, studies on cancer cell apoptosis and inhibition of cancer cell invasion has been conducted (2). In particular, various seaweeds have been reported to inhibit cancer cell growth (3-5). The majority of studies on seaweeds are conducted in Japan and Korea (6,7). Anti-tumor activity in

Correspondence to: Professor Taek-Jeong Nam, Institute of Fisheries Sciences, Pukyong National University, Ilgwang-ro, Ilgwang-myeon, Gijang-gun, Busan 619-911, Republic of Korea E-mail:namtj@pknu.ac.kr

Key words: Capsosiphon fulvescens, tight junction protein, cell invasion
HT-29 colon cancer cells using Laminaria japonica (8) and the recovery of damaged liver cells using Hizikia fusiformis (H.fusiformis) glycoprotein have been previously reported (9). In addition, inhibition of the growth of AGS human gastric cancer cells by a $H$. fusiformis extract has been noted (10).

Capsosiphon fulvescens (C.fulvescens) is a green alga that grows in clean areas off the Korean coast. $C$. fulvescens has long been a traditional Korean food and exhibits anti-cancer effects in addition to improving hangover symptoms, immune activity and anticoagulant activity. Anti-cancer effects of $C$. fulvescens components have been reported $(11,12)$. Prior to the present study, $C$. fulvescens glycoprotein treatment was reported to induce apoptosis of human gastric cancer AGS cells via Fas signaling (13). Increased $\beta$-catenin levels increase cell adhesion, leading to invasion and metastasis. These processes are accelerated in cancer cell metastasis and invasion mediated by adhesion between adjacent cancer cells; this is facilitated by increased $\beta$-catenin levels. Although cancer cell apoptosis is induced by Fas, $\beta$-catenin levels were decreased. Therefore, apoptosis was examined via Fas signaling; however, as invasion was not inhibited, further experiments were conducted.

The inhibitory effect of $C$. fulvescens on invasion by human gastric cancer AGS cells was also evaluated. Tight junction (TJ) and matrix metalloproteinase (MMP) proteins are overexpressed in a number of cancer cells and are associated with their invasive properties (14). Although MMP and TJ protein levels are increased, the transepithelial electrical resistance (TEER) value is lower. TEER facilitates material transfer between cells due to disrupted cell membrane permeability $(15,16)$. In addition, cancer cell adhesion, metastasis, proliferation and invasion increased. Therefore, studies of apoptosis signaling in cancer cells, as well as invasion and metastasis, have been performed recently. Therefore, in the present study, TJ proteins, claudin, zo-1 and occludin, and the cell adhesion-related molecules, $\beta$-catenin and E-cadherin, were investigated. $C$. fulvescens glycoprotein (Cf-GP) controls protein expression, which is associated with cancer cell invasion. Results indicate that Cf-GP treatment inhibits invasion and development of AGS human gastric cancer cells.

\section{Materials and methods}

Preparation of $C f$-GP. Cf-GP was purchased in 2006 in Korea. C.fulvescens powder $(40 \mathrm{~g})$ was diluted in 1 liter water 
and stirred for $3 \mathrm{~h}$ at $80^{\circ} \mathrm{C}$ using a heating mantle, followed by centrifugation at $1,500 \mathrm{xg}$ for $15 \mathrm{~min}$ at $4^{\circ} \mathrm{C}$.

Three volumes of $95 \%$ ethanol were added and precipitate was removed by vacuum filtration. To the supernatants, $80 \%$ ammonium sulfate was added, followed by stirring for $24 \mathrm{~h}$. Next, salt was removed by membrane dialysis (Por Membrane MW 3,500 Da, Spectrum Laboratories Inc., Rancho Dominguez, CA, USA) for 1 day at $4^{\circ} \mathrm{C}$. The concentrated solution was aliquoted into $1.5 \mathrm{ml}$ tubes and stored at $-70^{\circ} \mathrm{C}$ until use. These samples are hereafter termed Cf-GP.

Cell culture. Human gastric cancer AGS cells (American Type Culture Collection, Manassas, VA, USA) were maintained at $37^{\circ} \mathrm{C}$ in a $5 \% \mathrm{CO}_{2}$ humidified atmosphere. Cells were cultured in RPMI-1640 medium with $10 \%$ fetal bovine serum (FBS; Hyclone, Logan, UT, USA), $100 \mathrm{U} / 1$ penicillin and $100 \mathrm{mg} / \mathrm{l}$ streptomycin. Cells were cultured to $60-80 \%$ confluence in $100-\mathrm{mm}$ diameter dishes. The medium was replaced every day.

Cell proliferation assays. AGS cell proliferation was measured using a CellTiter $96^{\circledR}$ aqueous non-radioactivity cell proliferation assay (Promega Corporation, Madison, WI, USA). The assay is based on the cleavage of 3-(4,5-dimethylthiazol-2-yl)-5-(3-carboxymethoxy-phenyl)-2-(4-sulfonyl)-2H-tetrazolium (MTS) into a formazan product that is soluble in tissue culture media. Cells were seeded onto 96 -well plates at $2 \times 10^{4}$ cells/well in $100 \mu \mathrm{l}$ medium. Cells were maintained for $24 \mathrm{~h}$ and the medium was then replaced with serum-free medium (SFM). Following $24 \mathrm{~h}$, the medium was replaced with SFM containing Cf-GP $(0,5,10$ or $20 \mu \mathrm{g} / \mathrm{ml})$ for $24 \mathrm{~h}$. Cells were then incubated with MTS solution for $30 \mathrm{~min}$ at $37^{\circ} \mathrm{C}$. Cell proliferation was measured by means of absorbance at $490 \mathrm{~nm}$ using the Benchmark enzyme-linked immunosorbent assay (ELISA) plate reader (Bio-Rad, Hercules, CA, USA).

Cell invasion assays. Cell invasion was measured using an 8.0- $\mu \mathrm{m}$ pore size insert in Transwell ${ }^{\circledR}$ plates (Corning Costar Inc., Corning, NY, USA). AGS cells were seeded into the upper chamber (Matrigel coated; Corning Costar Inc.) and maintained for $24 \mathrm{~h}$. The medium was then replaced with SFM containing Cf-GP $(0,5,10$ or $20 \mu \mathrm{g} / \mathrm{ml})$ for $24 \mathrm{~h}$. The lower chamber was maintained with $10 \%$ FBS. Following $24 \mathrm{~h}$, the cut on the bottom of the filter (Matrigel coated) was stained with hematoxylin. Stained cells were calculated by extrapolation from the number counted.

TEER assay. Using a voltohmmeter (EVOM Epithelial Tissue Voltohmmeter; World Precision Instruments, Sarasota, FL, USA), TEER was measured. AGS cells were seeded into the upper chamber (Matrigel coated) of the transwell plates and maintained for $24 \mathrm{~h}$. Next, SFM was replaced with medium containing Cf-GP $(0,5,10$ or $20 \mu \mathrm{g} / \mathrm{ml})$ for $24 \mathrm{~h}$. The lower chamber was maintained with $10 \%$ FBS. Following $24 \mathrm{~h}$, the upper chamber was separated and TEER values were determined using the voltohmmeter.

TEER was calculated using the following formula: TEER $\left[\left(\right.\right.$ resistance $\left.\left(\Omega \mathrm{cm}^{2}\right)\right]=(\Omega$ - background $\Omega)$ x membrane area $\left(\mathrm{cm}^{2}\right)$; background resistance was 14 and the membrane area was $1.54 \mathrm{~cm}^{2}$. The change in TEER values for each insert was calculated using the following formula: change in $\operatorname{TEER}(\%)=\operatorname{TEER}\left(\Omega \mathrm{cm}^{2}\right) /$ initial TEER $\left(\Omega \mathrm{cm}^{2}\right)-100$.

$m R N A$ expression. AGS cells were seeded into six-well plates at $2 \times 10^{4}$ cells/well in $2 \mathrm{ml}$ medium. Cells were incubated for $24 \mathrm{~h}$ and the medium was replaced with SFM. Following $24 \mathrm{~h}$, the medium was replaced again with SFM containing Cf-GP $(0,5,10$ or $20 \mu \mathrm{g} / \mathrm{ml}$ ) for $24 \mathrm{~h}$. Cells were treated with the TRIzol reagent (Invitrogen Life Technologies, Carlsbad, CA, USA) and the RNA extracted was quantified using Oligo(dT) primers (Intron Biotechnology Co. Ltd., Seongnam, Korea); the corresponding cDNA was then synthesized. cDNA was subjected to amplification using a PCR kit (dNTP mix, 10X Ex Taq Buffer and Ex Taq; Takara Bio, Inc., Shiga, Japan) with primers (Table I) in $0.1 \%$ diethylpyrocarbonate water. PCR products were resolved on $1 \%$ agarose gels. Gels were stained with $10 \mathrm{mg} / \mathrm{ml}$ ethidium bromide to visualize amplification products.

Western blot analysis. AGS cells were cultured in 100-mm diameter dishes. Cells were cultured to $60-80 \%$ confluence and the medium was replaced with SFM for $4 \mathrm{~h}$. Next, the medium was replaced with fresh SFM containing Cf-GP $(0,5,10$ or $20 \mu \mathrm{g} / \mathrm{ml}$ ) for $24 \mathrm{~h}$. Cells were washed with phosphate-buffered saline and added to lysis buffer [50 mM Tris- $\mathrm{HCl}$ ( $\mathrm{pH} 7.4)$, $150 \mathrm{mM} \mathrm{NaCl}, 1 \mathrm{mM}$ EGTA, 1\% NP-40, $1 \mathrm{mM} \mathrm{NaF}, 1 \mathrm{mM}$ $\mathrm{Na}_{3} \mathrm{VO}_{4}, 1 \mu \mathrm{g} / \mathrm{ml}$ aprotinin, $1 \mu \mathrm{g} / \mathrm{ml}$ leupeptin, $1 \mu \mathrm{g} / \mathrm{ml}$ pepstatin A, $0.25 \%$ Na-deoxycholate and $1 \mathrm{mMPMSF}$. Lysates were separated using 10-15\% SDS-PAGE and transferred onto polyvinylidene fluoride membranes (Millipore, Billerica, MA, USA). The membranes were blocked with $1 \%$ bovine serum albumin in TBS-T [10 mM Tris- $\mathrm{HCl}(\mathrm{pH} 7.5), 150 \mathrm{mM} \mathrm{NaCl}$ and $0.1 \%$ Tween 20] at room temperature and incubated with agitation with specific antibodies: anti-claudin-1, $-2,-3$ and -4 $(1: 1,000)$, anti- $\beta$-catenin $(1: 1,000)$, anti-E-cadherin $(1: 1,000)$, anti-MMP-2 and $-9(1: 1,000)$ and anti-tissue inhibitors of metalloproteinases-1 (TIMP-1; 1:1,000; all from Santa Cruz Biotechnology, Inc., Santa Cruz, CA, USA). The secondary peroxidase-conjugated goat, mouse and rabbit antibodies $(1: 10,000)$ were purchased from GE Healthcare Bio-Sciences (Piscataway, NJ, USA). Bands were visualized using Super Signal West Pico Stable Peroxide solution and the Super Signal West Pico Luminol/Enhancer solution (Pierce Biotechnology, Inc., Rockford, IL, USA) and developed using Kodak X-ray film (Eastman Kodak Company, Rochester, NY, USA).

Gelatin zymography. AGS cells were cultured in six-well plates to $60-80 \%$ confluence and the medium was replaced with SFM for $4 \mathrm{~h}$. Next, the medium was replaced with fresh SFM containing Cf-GP $(0,5,10$ or $20 \mu \mathrm{g} / \mathrm{ml})$ for $24 \mathrm{~h}$. The obtained conditioned medium was loaded in $10 \%$ SDS-free acrylamide gels with $0.1 \%$ gelatin. The completed loading gel was treated with $2.5 \%$ Triton X-100 and incubated under agitation for $30 \mathrm{~min}$, followed by incubation with developing buffer $(50 \mathrm{mM}$ Tris-HCl, $150 \mathrm{mM} \mathrm{NaCl}, 5 \mathrm{mM} \mathrm{CaCl}_{2}$ and $1 \mu \mathrm{M} \mathrm{ZnCl}_{2} ; \mathrm{pH} 7.5$ ) at $37^{\circ} \mathrm{C}$ for 2 days. The gel was fixed ( $7 \%$ acetic acid) and stained (0.5\% Coomassie Brilliant Blue 250 in dilute fixing solution).

Statistical analysis. Data are presented as the mean \pm SD and were calculated using SPSS version 10.0 (SPSS, Inc., Chicago, IL, USA). Data were validated by analysis of 
Table I. Oligonucleotide sequences of the primer pairs used for RT-PCR.

Sequence of primers $\left(5^{\prime}-3^{\prime}\right)$

\begin{tabular}{lll}
\cline { 2 - 3 } Name & \multicolumn{1}{c}{ Sense } & \multicolumn{1}{c}{ Antisense } \\
\hline MMP-2 & GGC-CCT-GTC-ACT-CCT-GAG-AT & GGC-ATC-CAG-GTT-ATC-GGG-GA \\
MMP-9 & CGG-AGC-ACG-GAG-ACG-GGT-AT & TGA-AGG-GGA-AGA-CGC-ACA-GC \\
TIMP-1 & TGG-GGA-CAC-CAG-AAG-TCA-AC & TTT-TCA-GAG-CCT-TGG-AGG-AG \\
$\beta$-catenin & GAA-ACG-GCT-TTC-AGT-TGA-GC & CTG-GCC-ATA-TCC-ACC-AGA-GT \\
E-cadherin & GAA-CAG-CAC-GTA-CAC-AGC-CCT & GCA-GAA-GTG-TCC-CTG-TTC-CAG \\
Claudin-1 & TCA-GCA-CTG-CCC-TGC-CCC-AGT & TGG-TGT-TGG-GTA-AGA-GGT-TGT \\
Claudin-2 & ACA-CAC-AGC-ACA-GGC-ATC-AC & TCT-CCA-ATC-TCA-AAT-TTC-ATG-C \\
Claudin-3 & AAG-GCC-AAG-ATC-ACC-ATC-GTG & AGA-CGT-AGT-CCT-TGC-GGT-CGT \\
Claudin-4 & TGG-ATG-AAC-TGC-GTG-GTG-CAG & GCA-GAA-GTG-TCC-CTG-TTC-CAG \\
Occludin & TCA-GGG-AAT-ATC-CAC-CTA-TCA-CTT-CAG & CAT-CAG-CAG-CAG-CCA-TGT-ACT-CTT-CAC \\
Zo-1 & GAA-GCT-TCA-TCT-CCA-GTC-CCT & TGG-GTA-GGG-CTG-TTT-GTC-ATC-ATA \\
$\beta$-actin & CGT-ACC-ACT-GGC-ATC-GTG & GTG-TTG-GCG-TAC-AGG-TCT-TTG \\
\hline
\end{tabular}

MMP, matrix metalloproteinase; TIMP, tissue inhibitors of metalloproteinases.

variance (ANOVA). $\mathrm{P}<0.05$ was considered to indicate a statistically significant difference and was determined by Duncan's multiple range test for group comparisons.

\section{Results}

$C f$-GP inhibits AGS cell proliferation. MTS assays were used to investigate the effect of Cf-GP $(0,5,10$ or $20 \mu \mathrm{g} / \mathrm{ml})$ on AGS cell proliferation. Cf-GP at $20 \mu \mathrm{g} / \mathrm{ml}$ resulted in a $50 \%$ decrease in proliferation (Fig. 1). In addition, Cf-GP inhibited AGS cell growth in a dose-dependent manner. We previously reported that $\mathrm{Cf}-\mathrm{GP}$ induced proliferation of human intestinal epithelial IEC-6 cells (17).

$C f$-GP inhibits AGS cell invasion. In general, increased proliferation of cancer cells to other tissues is a result of accelerated invasion. Since Cf-GP inhibited AGS cell growth, the effect of Cf-GP on invasion was investigated using hematoxylin staining (Fig. 2A). As demonstrated in Fig. 2B, the Cf-GP treatment group exhibited decreased cell invasion compared with control cells. Treatment with $20 \mu \mathrm{g} / \mathrm{ml} \mathrm{Cf-GP}$ led to a $50 \%$ reduction compared with the control group.

$C f$-GP increases TEER values in AGS cells. Increased cell membrane permeability is mediated by weakening of TEER. We thus evaluated the effect of Cf-GP on AGS cell invasion by measuring TEER. Decreases of TEER values allowed easier penetration of intracellular material. Normal cells indicate higher TEER values by the strong electrical resistance of the cell membrane. However, MMP activity induced degradation of cell membranes and permeability in cancer cells. Therefore, cancer cells have lower TEER values and this increases invasion. In the present study, TEER values in AGS cells were increased upon Cf-GP treatment in a dose-dependent manner (Fig. 3).

Effect of Cf-GP on TJ-and metastasis-associated protein expression. The increased membrane permeability in cancer

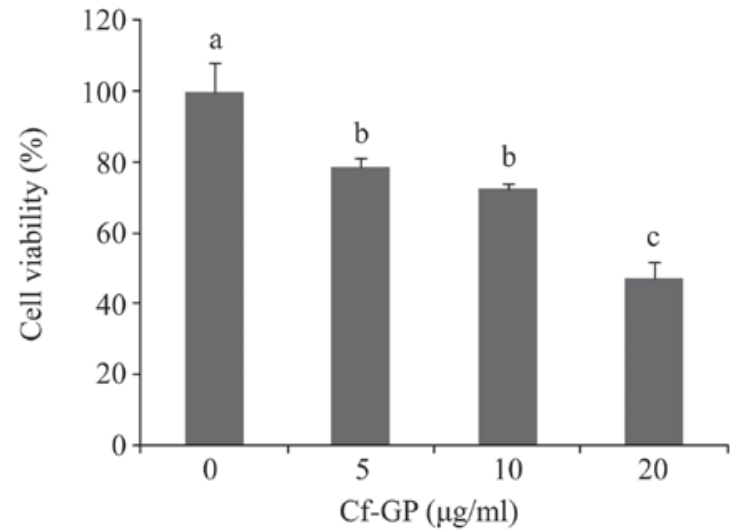

Figure 1. Cf-GP reduces the viability of AGS human gastric cancer cells. AGS cells were treated with $0,5,10$ or $20 \mu \mathrm{g} / \mathrm{ml} \mathrm{Cf-GP}$ for $24 \mathrm{~h}$. Cell viability was measured using the MTS assay. Data are presented as the means \pm SD; $\mathrm{P}<0.05$ by ANOVA. Values with different letters are significantly different according to Duncan's multiple range test. Cf-GP, Capsosiphon fulvescens glycoprotein. MTS, 3-(4,5-dimethylthiazol-2-yl)-5-(3-carboxymethoxy-phenyl)-2-(4-sulfonyl)-2H-tetrazolium.

cells is due to mutations in a variety of genes associated with TJ proteins. Typically, overexpression of TJ proteins (claudin, zo-1 and occludin) and TJ-related proteins ( $\beta$-catenin) is observed in cancer cells. In addition, $\beta$-catenin levels are increased due to loss of E-cadherin. Therefore, $\beta$-catenin increases cancer cell adhesion. In the present study, protein and mRNA levels were determined by western blot analysis and RT-PCR, respectively. As demonstrated in Fig. 4A and B, in control cells, expression levels of the TJ proteins, claudin, zo-1 and occludin increased, but were reduced in a dose-dependent manner upon Cf-GP treatment. In addition, $\beta$-catenin levels were reduced while that of the inhibitor of $\beta$-catenin, E-cadherin, was increased by Cf-GP treatment at the protein and mRNA levels (Fig. 4C and D).

Cf-GP inhibits MMP activity and expression. The interaction between cancer cells and the basement membrane is a major 


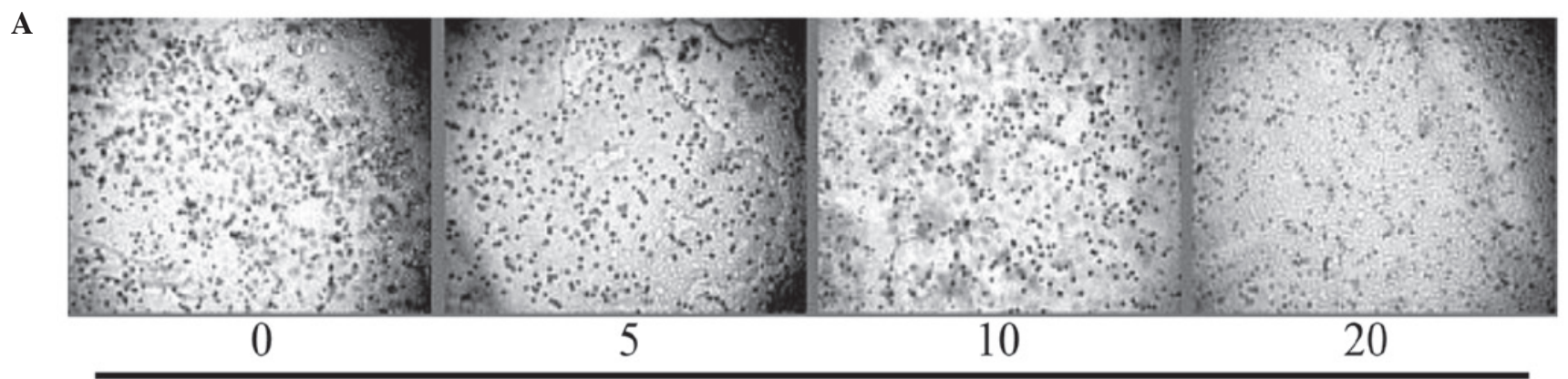

$\mathrm{Cf}-\mathrm{GP}(\mu \mathrm{g} / \mathrm{ml})$

B

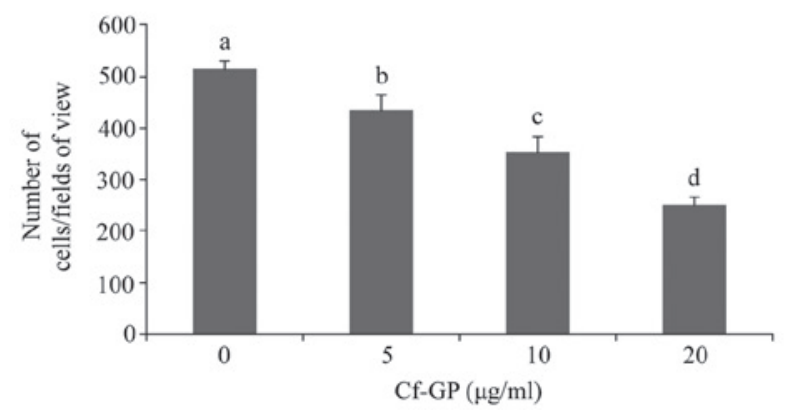

Figure 2. Inhibition of AGS cell invasion by Cf-GP. (A) Cells were seeded into Matrigel chambers for $24 \mathrm{~h}$. The medium was replaced with SFM plus Cf-GP $(0,5,10$ or $20 \mu \mathrm{g} / \mathrm{ml})$ for $24 \mathrm{~h}$. Invading cells on the bottom filter were stained with hematoxylin. (B) Cells in a random fixed area were counted. Cf-GP, Capsosiphon fulvescens glycoprotein; SFM, serum-free media. Data are presented as the means \pm SD; $\mathrm{P}<0.05$ by ANOVA. Values with different letters are significantly different according to Duncan's multiple range tests.

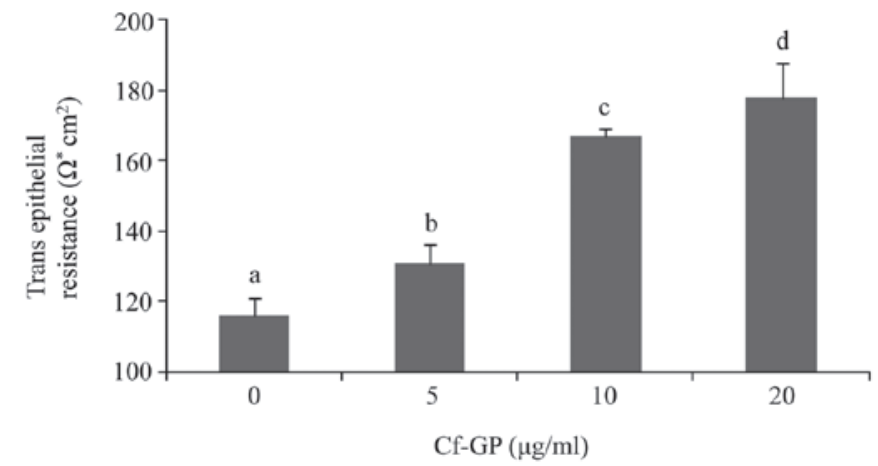

Figure 3. Increased TEER by Cf-GP in AGS cells. Cells were treated with various concentrations of Cf-GP $(0,5,10$ or $20 \mu \mathrm{g} / \mathrm{ml})$ for $24 \mathrm{~h}$. The lower chamber was maintained with $10 \%$ FBS. Following $24 \mathrm{~h}$, the upper chamber was separated and TEER values determined using the voltohmmeter. Data are presented as the mean $\pm \mathrm{SD} ; \mathrm{P}<0.05$ by ANOVA. Values with different letters are significantly different according to Duncan's multiple range tests. TEER, transepithelial electrical resistance; Cf-GP, Capsosiphon fulvescens glycoprotein; FBS, fetal bovine serum.

step in metastasis and invasion (18). The basement membrane is composed of substances, including collagen and lamin. Cell membrane degradation by MMP proteins and cancer cells is an important process for invasion and metastasis. In particular, MMP-2 and MMP-9 are important mediators of basement membrane degradation of gelatin and factors involved in angiogenesis and cancer cell invasion are known to induce MMP-2 and -9 (19). Thus, inhibition of MMP-2 and -9 is essential for preventing basement membrane destruction. MMP proteins were associated with TJ proteins and upregulation of TJ proteins induced MMP activation in cancer cells.
MMP activity leads to cell invasion and metastasis. In general, normal cells have tissue inhibitors of metalloproteinases (TIMPs). Therefore MMP activation and degradation of cell basement membrane are inhibited. However, cancer cells have constant proliferation and invasion by upregulation of TJ proteins and do not have TIMPs (20). In our previous study, expression of TJ proteins was confirmed. Therefore, MMP and TIMP levels were evaluated in AGS cells following treatment with Cf-GP. MMP-2 and -9 levels were decreased due to increased TIMP-1 as determined by western blot analysis and RT-PCR (Fig. 5A and B). In addition, gelatin zymography assays indicated that MMP protein levels decreased with increasing Cf-GP concentrations (Fig. 5C).

\section{Discussion}

Vividiffusion, division and gene expression are maintained by homeostasis in normal cells. However, in cancer cells, homeostasis is not maintained, enabling mutations to develop and invasion to continue. Therefore, cancer cell metastasis and invasion must be inhibited. MMP and TJ proteins are important for cancer cell invasion and metastasis, and are closely associated with cell membrane permeability (21). Invasion and metastasis of cancer cells occurs through degradation of the cell basement membrane by upregulation of MMP proteins (22). Cancer cell adhesion is affected by overexpression of proteins associated with cell membrane permeability. Increased MMP expression correlates with cancer cell metastasis and invasion $(23,24)$. In addition, expression of adhesion proteins is important for loss of invasion and metastatic capacities. TJ proteins are key for the passage through epithelial and endothelial barriers as well as in osmoregulation and 
A

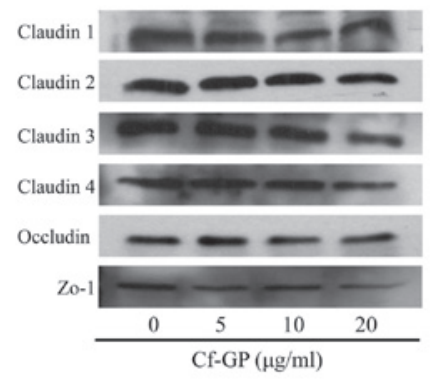

C

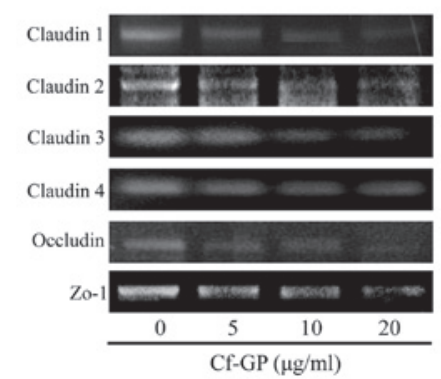

B

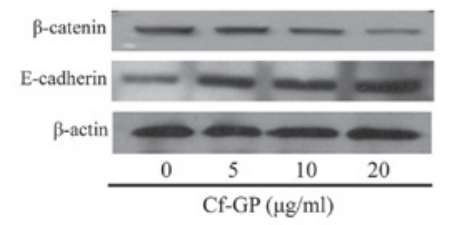

D

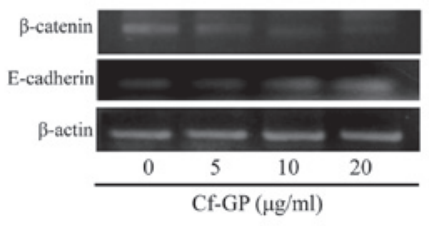

Figure 4. Effect of Cf-GP on TJ proteins in AGS cells. Protein expression was examined by western blot analysis and cDNAs were subjected to PCR. Reaction products were electrophoresed in a $1 \%$ agarose gel and visualized by ethidium bromide staining. (A) Expression of TJ proteins were decreased upon incubation with Cf-GP for 24 h. (B) mRNA levels were also decreased, as revealed by RT-PCR. (C) Decreased levels of cell adhesion protein ( $\beta$-catenin) and increased E-cadherin, which inhibits $\beta$-catenin. (D) Consistent $\beta$-catenin and E-cadherin results at the mRNA level as determined by RT-PCR. Cf-GP, Capsosiphon fulvescens glycoprotein; TJ, tight junction.

A

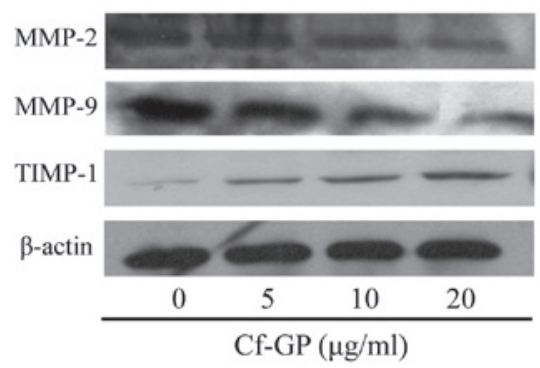

B

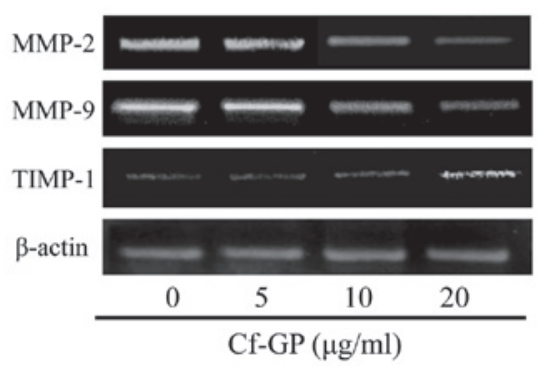

C

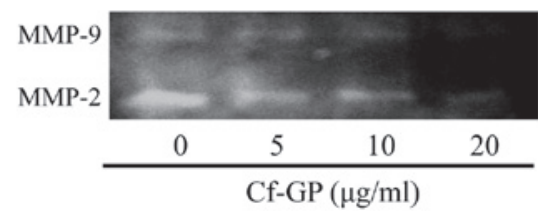

Figure 5. Effect of Cf-GP on MMP and TIMP-1 protein expression in AGS cells. (A and B) Cells were treated with 0,5, $10 \mathrm{or} 20 \mu \mathrm{g} / \mathrm{ml} \mathrm{Cf-GP}$ for $24 \mathrm{~h}$. Western blot analysis and RT-PCR were performed as described. (C) AGS cells were cultured in six-well plates and treated with Cf-GP $(0,5,10 \mathrm{or} 20 \mu \mathrm{g} / \mathrm{ml})$ for $24 \mathrm{~h}$ and analyzed by gelatin zymography. Cf-GP, Capsosiphon fulvescens glycoprotein; MMP, matrix metalloproteinase; TIMP, tissue inhibitors of metalloproteinases.

maintenance of cell polarity (25-27). Therefore, cancer cell membrane permeability is weakened due to overexpression of $\mathrm{TJ}$ and MMP proteins, resulting in enhanced metastasis and invasion. Expression levels of the TJ proteins, claudin, zo-1 and occludin, are increased, resulting in the inhibition of invasion and metastasis by cancer cells $(28,29)$. Changes in cell membrane permeability are induced by increased expression of claudin, zo-1 and occludin. In addition, TEER values are decreased by overexpression of TJ proteins (30). Therefore, suppression of claudin, zo-1 and occludin is important for inhibition of metastasis and invasion. In addition, increased expression of $\beta$-catenin facilitates invasion and metastasis of cancer cells, which is mediated by the simultaneous actions of MMP and TJ proteins. Thus, expression of $\beta$-catenin and E-cadherin is important $(31,32)$. In normal cells, E-cadherin inhibits $\beta$-catenin, which is associated with cell adhesion, inhibiting its nuclear accumulation. Since E-cadherin expression is decreased in cancer cells, $\beta$-catenin accumulates in the nucleus, resulting in enhanced adhesion. Cell membrane permeability is impeded by increased MMP and TJ expression, while adhesion is enhanced, resulting in the rapid proliferation of cancer cells. Previous studies using Cf-GP revealed that apoptosis of AGS cells was associated with Fas signaling (17) and that $\beta$-catenin expression was reduced during apoptosis. Therefore, the effect of Cf-GP on AGS human gastric cancer cell invasion and metastasis was investigated. 
Cf-GP treatment $(0,5,10$ or $20 \mu \mathrm{g} / \mathrm{ml})$ for $24 \mathrm{~h}$ inhibited the growth of AGS cells. The Cf-GP-treated group exhibited decreased cell invasion and increased TEER. The latter is based on the electrical resistance of the cell membrane and is closely associated with cell invasion due to its association with cell membrane permeability. Next, the expression levels of associated proteins, MMPs, TIMP-1, claudin, zo-1, occludin, $\beta$-catenin and E-cadherin, were evaluated. Dose-dependent decreases in MMP expression and increases in TIMP-1 expression, an MMP inhibitor, were identified following Cf-GP treatment for $24 \mathrm{~h}$ at the protein and mRNA levels. In addition, MMP-2 and -9 levels were observed by gelatin zymography, confirming inhibition at the protein level. As a result, compared with the control group, Cf-GF-treated cells exhibited significantly decreased claudin, zo-1 and occludin protein and mRNA levels. This result confirmed that suppression of cancer cell invasion is mediated by inhibition of TJ protein expression.

In summary, Cf-GP decreased MMP expression in a dose-dependent manner. MMP expression is associated with cell basement membrane degradation factor and inhibition of the TJ proteins involved in membrane permeability. Inhibition of AGS growth and invasion was confirmed. Anti-tumor activity in various cell lines using marine algae has been previously reported and results of the present study indicate the promise of functional therapeutics using Cf-GP.

\section{Acknowledgements}

This study was supported by the Basic Science Research Program through the National Research Foundation of Korea funded by the Ministry of Education, Science and Technology (no. 2012R1A6A1028677).

\section{References}

1. Bishop JM: The molecular genetics of cancer. Science 235 305-311, 1987.

2. Kim SO, Choi YH and Choe WK: Indol-3-carbinol regulated tight junction permeability and associated-protein level and suppressed cell invasion in human colon cancer cell line, HT-29. Korean J Nutr 41: 13-21, 2008.

3. Higashi-Okaj K, Otani S and Okai Y: Potent suppressive effect of a Japanese edible seaweed, Enteromorpha prolifera (Sujiao-nori) on initiation and promotion phases of chemically induced mouse skin tumorigenesis. Cancer Lett 140: 21-25, 1999.

4. Okai Y, Higashi-Okai K, Nakamura S, Yano Y and Otani S: Suppressive effects of the extracts of Japanese edible seaweeds on mutagen-induced umu $\mathrm{C}$ gene expression in Salmonella typhimurium (TA $1535 / \mathrm{pSK} 1002$ ) and tumor promoter-dependent ornithine decarboxylase induction in BALB/c 3T3 fibroblast cells. Cancer Lett 87: 25-32, 1994.

5. Yamamoto I, Maruyama $\mathrm{H}$ and Moriguchi M: The effect of dietary seaweeds on 7,12-dimethylbenz[a]anthracene-induced mammary tumorigenesis in rats. Cancer Lett 35: 109-118, 1987.

6. Noda H, Amano H, Arashima K and Nisizawa K: Antitumor activity of marine algae. Hydrobiologia 204-205: 577-584, 1990.

7. Kwon MJ and Nam TJ: Porphyran induces apoptosis related signal pathway in AGS gastric cancer cell lines. Life Sci 79: 1956-1962,2006.

8. Go H, Hwang HJ and Nam TJ: A glycoprotein from Laminaria japonica induces apoptosis in HT-29 colon cancer cells. Toxicol in Vitro 24: 1546-1553, 2010.

9. Hwang HJ, Kim IH and Nam TJ: Effect of a glycoprotein from Hizikia fusiformis on acetaminophen-induced liver injury. Food Chem Toxicol 46: 3475-3481, 2008.

10. Choi YH: Inhibition of cell invasion by ethyl alcohol extracts of Hizikia fusiforme in AGS human gastric adenocarcinoma cells. Korea J Life Sci 20: 1784-1791, 2010.
11. Cho EK, Yoo SK and Choi YJ: Inhibitory effects of maesaengi (Capsosiphon fulvescens) extracts on angiotensin converting enzyme and $\alpha$-glucosidase. Korea J Life Sci 21: 811-818, 2011.

12. Park HY, Lim CW, Kim YK, Yoon HD and Lee KJ: Immunostimulating and anti-cancer activities of hot water extract from Capsosiphon fulvescens. J Korean Soc Appl Biol Chem 49: 343-348, 2006.

13. Kim YM, Kim IH and Nam TJ: Induction of apoptosis signaling by a glycoprotein of Capsosiphon fulvescens in AGS cell. Kor J Fish Aquat Sci 44: 216-224, 2011.

14. Peralta SA, Mullin JM, Knudsen KA and Marano CW: Tissue remodeling during tumor necrosis factor-induced apoptosis in LLC-PK1 renal epithelial cells. Am J Physiol 270: F869-F879, 1996.

15. Swift JG, Mukherjee TM and Rowland R: Intercellular junctions in hepatocellular carcinoma. J Submicrosc Cytol 15: 799-810, 1983.

16. Van Itallie CM and Anderson JM: The molecular physiology of tight junction pores. Physiology (Bethesda) 19: 331-338, 2004.

17. Kim YM, Kim IH and Nam TJ: Induction of apoptosis signaling by glycoprotein of Capsosiphon fulvescens in human gastric cancer (AGS) cells. Nutr cancer 64: 761-769, 2012.

18. Lamszus K, Kunkel P and Westphal M: Invasion as limitation to anti-angiogenic glioma therapy. Acta Neurochir Suppl 88: $169-177,2003$.

19. Duffy MJ, Maguire TM, Hill A, McDermott E and O'Higgins N: Metalloproteinases: role in breast carcinogenesis, invasion and metastasis. Breast Cancer Res 2: 252-257, 2000.

20. Curry JD, Glaser MC and Smith MT: Real-time reverse transcription polymerase chain reaction detection and quantification of $\mathrm{t}(1 ; 19)(\mathrm{E} 2 \mathrm{~A}-\mathrm{PBX} 1)$ fusion genes associated with leukemia. $\mathrm{Br}$ J Haematol 115: 826-830, 2001.

21. Park HS, Kim GY, Choi IW, Kim ND, Hwang HJ, Choi YW and Choi YH: Inhibition of matrix metalloproteinase activities and tightening of tight junctions by diallyl disulfide in AGS human gastric carcinoma cells. J Food Sci 76: T105-T111, 2011.

22. Coussens LM and Werb Z: Matrix metalloproteinases and the development of cancer. Chem Biol 3: 895-904, 1996.

23. Bennett JH, Morgan MJ, Whawell SA, Atkin P, Roblin P, Furness J and Speight PM: Metalloproteinase expression in normal and malignant oral keratinocytes: stimulation of MMP-2 and MMP-9 by scatter factor. Eur J Oral Sci 108: 281-291, 2000.

24. Ylisirniö S, Höyhtyä M and Turpeenniemi-Hujanen T: Serum matrix metalloproteinases $-2,-9$ and tissue inhibitors of metalloproteinases $-1,-2$ in lung cancer-TIMP-1 as a prognostic marker. Anticancer Res 20: 1311-1316, 2000.

25. Song ES, Lee BI, Kim JM, Lee KY, An KS, Sung SM, Kwon HJ, Park JH, Han JY and Choi SJ: Increase expressions of claudin-1 and claudin-7 in cervical squamous intraepithelial neoplasias and invasive squamous cell carcinomas. Korean J Obstet Gynecol 49: 1065-1072, 2006.

26. Langbein L, Grund C, Kuhn C, Praetzel S, Kartenbeck J, Brandner JM, Moll I and Franke WW: Tight junctions and compositionally related junctional structures in mammalian stratified epithelia and cell cultures derived therefrom. Eur J Cell Biol 81: 419-435, 2002.

27. Tsukita S and Furuse M: Pores in the wall: claudins constitute tight junction strands containing aqueous pores. J Cell Biol 149: 13-16, 2000.

28. Agarwal R, D'Souza T and Morin PJ: Claudin-3 and claudin-4 expression in ovarian epithelial cells enhances invasion and is associated with increased matrix metalloproteinase-2 activity. Cancer Res 65: 7378-7385, 2005.

29. Balda MS, Garrett MD and Matter K: The ZO-1-associated Y-box factor ZONAB regulates epithelial cell proliferation and cell density. J Cell Biol 160: 423-432, 2003.

30. Lee H, Kim D, Sohn D, Jeong B, Choi H, Sim K, Lee K, Cho H, Kim S, Lee J, Jeong Y, Kim S, Lee W and Kim K: The changes of occludin in tight junction of blood-brain barrier by ROS. Korean J Electron Microscopy 34: 231-239, 2004.

31. Tunggal JA, Helfrich I, Schmitz A, Schwarz H, Günzel D, Fromm M, Kemler R, Krieg T and Niessen CM: E-cadherin is essential for in vivo epidermal barrier function by regulating tight junctions. EMBO J 24: 1146-1156, 2005.

32. Mess ST, Mennigen R, Spieker T, Rijcken E, Senninger N, Haier $\mathrm{J}$ and Bruewer $\mathrm{M}$ : Expression of tight and adherens junction proteins in ulcerative colitis associated colorectal carcinoma: upregulation of claudin-1, claudin-3, claudin-4 and $\beta$-catenin. Int J Colorectal Dis 24: 361-368, 2009. 